\title{
Reciprocal combinations of barley and corn grains in oil-supplemented diets: Feeding behavior and milk yield of lactating cows
}

\author{
S. Kargar, ${ }^{* 1,2}$ G. R. Ghorbani, ${ }^{*}$ M. Khorvash, ${ }^{*}$ A. Sadeghi-Sefidmazgi, ${ }^{*}$ and D. J. Schingoethe† \\ *Department of Animal Sciences, College of Agriculture, Isfahan University of Technology, Isfahan 84156-83111, Iran \\ †Dairy Science Department, South Dakota State University, Brookings 57007-0647
}

\begin{abstract}
The effect of barley-based (BBD) or corn-based diets (CBD), or their equal blend (BCBD) on dry matter (DM) intake, feeding and chewing behavior, and production performance of lactating dairy cows was evaluated. Nine multiparous Holstein cows $(75.6 \pm 11.0 \mathrm{~d}$ in milk) were used in a triplicate $3 \times 3$ Latin square design with 21-d periods. Forage-to-concentrate ratio (40:60), forage neutral detergent fiber (20\% of DM), total neutral detergent fiber $(>29 \%$ of $\mathrm{DM})$, and geometric mean particle size $(4.3 \mathrm{~mm})$ were similar among treatments. Meal patterns, including meal size and intermeal interval, were not affected by the dietary treatments and DM intake $(25.6 \mathrm{~kg} / \mathrm{d})$ was not different among treatments. Ether extract intake increased linearly with increasing amount of the corn grain in the diets. Due to similar feed intake, actual milk (48.6 $\mathrm{kg} / \mathrm{d}), 4 \%$ fat-corrected milk $(36.8 \mathrm{~kg} / \mathrm{d})$, and fat- and protein-corrected milk $(38.1 \mathrm{~kg} / \mathrm{d})$ yields were not affected by treatments. Average milk protein percentage and yield were $2.83 \%$ and $1.37 \mathrm{~kg} / \mathrm{d}$, respectively, and were not different across treatments. Milk fat percentage increased linearly with increasing amount of corn grain in the diets and was greater in CBD relative to BCBD but not BBD $(2.31,2.28$, and $2.57 \%$, for BBD, $\mathrm{BCBD}$, and $\mathrm{CBD}$, respectively). However, milk fat yield tended to show a linear increase as the amount of corn grain included in the diets increased. Results indicated that changing diet fermentability by replacing barley grain for corn grain in oil-supplemented diets did not influence feeding patterns and thereby no changes in feed intake and milk yield occurred.
\end{abstract}

Key words: barley and corn grain, feeding and chewing behavior, dairy cow

Received December 18, 2013.

Accepted July 25, 2014.

${ }^{1}$ Present address: Department of Dairy Science, College of Agriculture and Life Sciences, University of Wisconsin-Madison, Madison 53706-1284.

${ }^{2}$ Corresponding author: kargar@ag.iut.ac.ir or skargar@wisc.edu

\section{INTRODUCTION}

Dietary type of grain (barley vs. corn) resulted in varied DMI and milk yield responses in different research experiments. Overton et al. (1995) fed dairy cows diets containing 5 different ratios of starch from ground shelled corn grain and steam-rolled barley grain and found that DMI and milk yield decreased as the ratio of starch from steam-rolled barley grain increased, which was because of increased ruminal digestibility of starch from barley grain. Khorasani et al. (2001) also fed 3 different ratios of barley and corn grain to dairy cows and reported that substitution of barley grain with corn grain resulted in a quadratic response in DMI and milk yield. Overton et al. (1995) but not Khorasani et al. (2001) reported that milk fat percentage was affected quadratically by the proportion of barley grain and corn grain in the diets, such that the percentage of fat was greatest when diets contained barley grain and corn grain in ratios of 100:0 and 0:100 and was lowest when blends of barley grain and corn grain were fed to cows. In our recent experiment (Kargar et al., 2013), cows fed barley-based diets tended to increase DMI and had numerically greater milk yield compared with cows fed corn-based diets. Furthermore, grain type did not affect milk fat concentration and yield (Kargar et al., 2013). Increasing ruminal digestion of starch can increase milk yield through increased total-tract digestibility of feed and increased microbial protein synthesis, if acidosis is avoided with sufficient concentration of physically effective fiber in the diet (Allen, 2000; Beauchemin and Yang, 2006). Accordingly, greater ruminal fermentation is more of interest to increase energy intake and also microbial protein yield, but DMI is reduced. Therefore, it is important to understand mechanisms by which DMI and milk yield are influenced when cows are fed diets containing grains differing in expected ruminal fermentability.

Feed intake is a function of both meal size and intermeal interval, determined by satiety and hunger, respectively (Allen, 2000; Kargar et al., 2013). Type of grain and its starch susceptibility to ruminal digestion has a contradictory effect on meal patterns (Oba 
and Allen, 2003; Kargar et al., 2013). Diets high in ruminally degraded starch (e.g., high-moisture corn grain vs. dry corn grain) decreased DMI by decreasing meal size without affecting milk yield and ruminating time (Oba and Allen, 2003). However, barley-based diets (BBD) increased ruminating time by increasing rumination duration compared with corn-based diets (CBD; Kargar et al., 2013). Therefore, investigation of feeding behavior when cows are fed diets containing grains differing in expected ruminal fermentability is required to clarify regulation mechanisms for feed intake.

Forage particle size is considered as one of the key determinants of the physical effectiveness of diets in dairy cows, as it promotes stratification of digesta in the reticulorumen, which positively affects eating and ruminating activities as well as rumen buffering (Mertens, 1997; Nasrollahi et al., 2012). All these processes are critical to maintain proper rumen function and optimize digestion, feed intake, and nutrient utilization (NRC, 2001; Tafaj et al., 2007; Nasrollahi et al., 2012). Furthermore, previous studies have reported that the effects of forage particle size are also related to the degradation properties of the diet (Silveira et al., 2007; Nasrollahi et al., 2012). For example, it has been shown that for the same forage particle size in the diet, the physiological responses obtained are different when these diets are based on barley grain versus corn grain (Beauchemin and Rode, 1997; Nasrollahi et al., 2012). In an experiment, Nasrollahi et al. (2012) concluded that feeding of long versus fine alfalfa hay (theoretical length cut of 30 vs. $15 \mathrm{~mm}$ ) is more critical for barley- versus a mixture of barley- and corn-based diets to avoid reduction of feed intake and fiber digestion in mid-lactation dairy cows. In a constant level of forage particle size (theoretical length cut of $30 \mathrm{~mm}$ ), however, it is not known whether changing diet fermentability (using grains different in expected ruminal fermentation) when supplemented with unsaturated oil would affect lactational performance and eating and ruminating activities. Most experiments that have considered the effect of grain type and fat supplementation of the diet have used a type of rumen-inert fat (Sadri et al., 2009; Nasrollahi et al., 2012). Therefore, it remains unclear how performance and behavior of dairy cows would be influenced by changing fermentability of diets supplemented with unsaturated oil.

Oil supplements are commonly used for increasing energy density of diets fed to high-producing dairy cows. Previous experiments have shown that feeding oil supplements (e.g., $\leq 2 \%$ of dietary DM) to dairy cows, particularly when diets contain a high level of concentrate, could maintain or improve lactation performance with minimal interference on fermentation and nutrient intake (Kargar et al., 2010, 2012, 2013). Furthermore, addition of oil to the diet increased energy density without sacrificing dietary fiber concentration and increased rumen acid production, thus stabilizing rumen $\mathrm{pH}$ relative to the addition of grain (Kargar et al., 2010, 2012).

The objective of this work was to evaluate the effect of substituting barley grain with corn grain on feed intake, lactational performance, and feeding and chewing behavior of Holstein cows fed high-concentrate diets supplemented with oil. We hypothesized that a barley-based diet would decrease intake and, thereby, milk yield, relative to a corn-based diet through signaling decreased meal size or increased intermeal interval.

\section{MATERIALS AND METHODS}

All procedures were conducted under protocols approved by the Isfahan University of Technology (IUT) Laboratory Animal Care Advisory Committee (Isfahan, Iran). The experiment was conducted in Lavark at the Farm Animal Research and Teaching Unit of IUT.

\section{Animals, Experimental Design, and Treatments}

Nine lactating multiparous Holstein cows (BW = $656.0 \pm 49.0 \mathrm{~kg}$; parity $=2.7 \pm 0.7$; mean \pm SD) $75.6 \pm$ 11.0 DIM and producing $49.2 \pm 3.2 \mathrm{~kg}$ of milk/d with $3.00 \%$ fat and $2.91 \%$ protein were used in a replicated $3 \times 3$ Latin square design with 21 -d periods. Each experimental period consisted of a 16-d diet adaptation period and a 5-d collection period. Cows were grouped into 3 squares of 3 cows each based on milk yield and DIM (i.e., 3 cows with the roughly similar milk yield and DIM were considered as a square). Cows within square were randomly assigned to dietary sequences to minimize carryover effects. Therefore, cows received 1 of the 3 following experimental diets: (1) barley-based diet (BBD), (2) barley- and corn-based diet (BCBD), and (3) corn-based diet (CBD; Table 1). Cows were housed individually in box stalls $(4 \times 4 \mathrm{~m})$ located in a roofed area with open sides. Each box stall was equipped with a concrete feed bunk and automatic water troughs. Clean wood shavings and sand were used for bedding and refreshed twice daily. Cows were allowed to exercise in an outdoor lot daily from 1700 to $1800 \mathrm{~h}$. Barley and corn grains were selected, as dairy cow diets in Iran and many places in the world typically contain any one or combinations of these cereal grains as the principal source of energy. Grains were ground using a hammer mill with 3-mm screen size (model 5543 GEN; Isfahan Dasht, Isfahan, Iran). The BBD and CBD contained 33.3 and $28.0 \%$ barley grain and corn grain as the sole types of grain, respectively, whereas BCBD had an 
equal blend of $(15.5 \%)$ those grains. The main protein sources for the experimental diets were soybean meal, canola meal, and corn gluten meal (Table 1). Soybean meal compared with canola meal and also corn grain versus barley grain have greater energy values and, thereby, ME allowable for milk (NRC, 2001). To more closely match ME concentration of the diets, soybean meal was used mainly in $\mathrm{BBD}$, whereas canola meal was used mainly in CBD (Beauchemin and Rode, 1997; Kargar et al., 2013). Soybean and fish oils were added to the concentrate such that experimental diets would contain 4 to $4.5 \%$ fat (on a DM basis). The forage-toconcentrate ratio of the diets was 40:60. The forage component of the experimental diet was a mixture of corn silage and chopped alfalfa hay. However, beet pulp was included in all dietary treatments at the level $(4.5 \%$ of dietary DM) that provides some additional digestible fiber. Second-cut alfalfa hay at 50\% flowering was chopped with a theoretical length of $30 \mathrm{~mm}$, using a harvesting machine with screen size regulator (Golchin Trasher Hay Co., Isfahan, Iran). Diets were formulated to meet or exceed the Cornell Net Carbohydrate and
Protein System (version 5.0) nutrient allowance for a lactating dairy cow weighing $656 \mathrm{~kg}$ and producing 43 $\mathrm{kg} / \mathrm{d}$ of milk with $3.0 \%$ milk true protein and $3.2 \%$ fat and consuming $23.9 \mathrm{~kg}$ of DM. Dietary ingredients were mixed for approximately $8 \mathrm{~min}$ in a TMR mixer wagon (Fan Avaran Keshavarzi Arya Co., Isfahan, Iran). Soybean and fish oils were incorporated into the concentrate fraction and then added to the TMR. After mixing, the ration was transferred to a feed cart (Iran Plast Co., Isfahan, Iran) from which cows were fed. Feed was supplied twice daily at 0900 and $1500 \mathrm{~h}$ in amounts that allowed $10 \%$ refusals. Forty percent of the daily allocation was provided at the morning feeding, and $60 \%$ was given at the afternoon feeding.

\section{Feed Sampling and Analyses}

The TMR amounts offered and refused were measured daily for each cow and DMI determined daily for each cow. To determine DM and nutrient composition, representative samples of forages (pooled within period), treatment TMR (pooled by diet within period),

Table 1. Ingredients and chemical composition (with SD in parentheses) of the experimental diets on a DM basis

\begin{tabular}{|c|c|c|c|}
\hline \multirow[b]{2}{*}{ Item } & \multicolumn{3}{|c|}{$\operatorname{Diet}^{1}$} \\
\hline & $\mathrm{BBD}$ & $\mathrm{BCBD}$ & CBD \\
\hline \multicolumn{4}{|c|}{ Ingredient composition, $\%$ of DM } \\
\hline Corn silage & 19.00 & 19.00 & 19.00 \\
\hline Alfalfa hay & 21.00 & 21.00 & 21.00 \\
\hline Beet pulp & 4.49 & 4.49 & 4.49 \\
\hline Barley grain (ground) & 33.32 & 15.46 & - \\
\hline Corn grain (ground) & - & 15.46 & 28.00 \\
\hline Soybean meal & 14.05 & 11.28 & 8.47 \\
\hline Canola meal (pelleted) & 2.51 & 7.39 & 12.89 \\
\hline Corn gluten meal & 1.00 & 1.29 & 1.52 \\
\hline Soybean oil & 1.67 & 1.67 & 1.67 \\
\hline Fish oil & 0.33 & 0.33 & 0.33 \\
\hline Sodium bicarbonate & 0.75 & 0.75 & 0.75 \\
\hline Calcium carbonate & 0.29 & 0.29 & 0.29 \\
\hline Calcium phosphate (mono) & 0.29 & 0.29 & 0.29 \\
\hline Vitamin-mineral premix ${ }^{2}$ & 1.05 & 1.05 & 1.05 \\
\hline Salt & 0.25 & 0.25 & 0.25 \\
\hline \multicolumn{4}{|l|}{ Chemical composition } \\
\hline DM, \% & $53.79(2.24)$ & $53.92(2.35)$ & $54.05(2.23)$ \\
\hline $\mathrm{OM}, \%$ of $\mathrm{DM}$ & $91.28(2.01)$ & $90.95(2.13)$ & $90.95(2.01)$ \\
\hline $\mathrm{CP}, \%$ of DM & $17.66(0.53)$ & $17.36(0.75)$ & $17.53(0.21)$ \\
\hline $\mathrm{NFC}^{3} \%$ of DM & $38.28(0.68)$ & $39.58(0.31)$ & $39.24(0.73)$ \\
\hline $\mathrm{NDF}, \%$ of DM & $31.38(0.78)$ & $29.83(1.36)$ & $29.33(2.48)$ \\
\hline Ether extract, $\%$ of DM & $3.79(0.34)$ & $4.11(0.41)$ & $4.59(0.52)$ \\
\hline Ash, $\%$ of DM & $8.88(0.15)$ & $9.04(0.16)$ & $9.06(0.12)$ \\
\hline $\mathrm{NE}_{\mathrm{L}},{ }^{4} \mathrm{Mcal} / \mathrm{kg}$ of DM & 1.71 & 1.73 & 1.74 \\
\hline
\end{tabular}


and individual refusals (pooled by cow within period) were taken immediately before the morning feeding during the 5-d collection period. Also, additional samples of forages, treatment TMR, and individual refusals of each cow were taken for particle size separation during the same time of each experimental period. All samples were immediately frozen at $-20^{\circ} \mathrm{C}$ until they were analyzed.

After thawing, particle size distributions of representative subsamples of the samples taken were determined using the Penn State Particle Separator [PSPS (The Pennsylvania State University, University Park); Nasco, Fort Atkinson, WI] equipped with 3 sieves $(19,8$, and $1.18 \mathrm{~mm}$ ) and a pan. This separated the particles into 4 fractions: long $(>19 \mathrm{~mm})$, medium $(\geq 8$ and $<19 \mathrm{~mm})$, short $(\geq 1.18$ and $<8 \mathrm{~mm})$, and fine $(<1.18 \mathrm{~mm})$ particles. After separation, the DM of each separated fraction was determined by oven drying at $60^{\circ} \mathrm{C}$ for $48 \mathrm{~h}$. The physical effectiveness factor (pef) was determined as the DM proportion of particles retained on 2 sieves (pef $_{>8}$; Lammers et al., 1996) and on 3 sieves (pef $>1.18$; Kononoff et al., 2003) of the PSPS. The amounts of physically effective NDF of $2\left(\mathbf{p e N D F}_{>8}\right)$ and 3 sieves $\left(\mathbf{p e N D F} \mathbf{F}_{>1.18}\right)$ were calculated by multiplying the NDF concentration of the feed by the fraction on pef $_{>8}$ and pef $_{>1.18}$, respectively.

The DM concentration of composited forages, treatment TMR, and refusal samples was determined by drying at $60^{\circ} \mathrm{C}$ in a forced-air oven for $48 \mathrm{~h}$ and $\mathrm{DM}$ results were adjusted to $100^{\circ} \mathrm{C}$ according to AOAC International (2002; method 925.40). All samples were ground using a Wiley mill through a 1-mm screen (Arthur H. Thomas Co., Philadelphia, PA) and analyzed in triplicate for CP using the Kjeldahl method [Kjeltec 1030 Auto Analyzer (Foss Tecator AB, Höganäs, Sweden); AOAC International, 2002; method 955.04], ether extract (EE; AOAC International, 2002; method 920.39), ash (AOAC International, 2002; method 942.05), and NDF using a heat-stable $\alpha$-amylase $(100 \mu \mathrm{L} / 0.5 \mathrm{~g}$ of sample) and sodium sulfite (Van Soest et al., 1991). The NFC component was calculated as $100-(\mathrm{CP}+$ $\mathrm{NDF}+\mathrm{EE}+\mathrm{ash})$. Refusals from individual cows were used for calculation of nutrient intake.

\section{Sorting Behavior and Chewing Activities}

The sorting index was calculated as the ratio of actual intake to expected intake for particles retained on each sieve of the PSPS (Leonardi and Armentano, 2003). The predicted intake of an individual fraction was calculated as the product of the DMI of the total diet multiplied by the DM percentage of that fraction in the fed TMR. A sorting index of 100, >100, and
$<100$ indicated no sorting, sorting for, and sorting against, respectively.

On the third day of each collection period, eating and ruminating activities were monitored visually for a $24-\mathrm{h}$ period. Activities were noted every $5 \mathrm{~min}$, and each activity was assumed to persist for the entire 5-min interval between observations. To estimate time spent eating or ruminating per kilogram of DM, NDF, forage $\mathrm{NDF}, \mathrm{peNDF}_{>8}$, and $\mathrm{peNDF}_{>1.18}$ intake, average intake within the experimental period was used. A period of rumination was defined as at least 5 min of ruminating activity followed by at least $5 \mathrm{~min}$ without ruminating activity. Total chewing time was calculated as the sum of eating and ruminating time. In addition, the number of chews per bolus was enumerated during each rumination period for each cow. The first 10 boluses for a rumination period were recorded and averaged to obtain a bolus chewing number for that rumination event (Kargar et al., 2010, 2013).

\section{Milk Yield and Components}

Cows were milked 3 times daily at 0200, 1000, and $1800 \mathrm{~h}$ in a herringbone milking parlor. Milk yield for all cows was recorded and sampled at each milking during the 5 -d collection period. Before each milking, cows were monitored for udder inflammation and presence of milk clots to ensure that milk yield and composition were not affected by different forms of mastitis. Milk samples were composited in proportion to milk yield, preserved with potassium dichromate, stored at $4^{\circ} \mathrm{C}$, and submitted to the IUT Central Milk Testing Laboratory for fat and protein analyses using an infrared analyzer [MilkoScan 134 BN (Foss Electric A/S, Hillerød, Denmark); AOAC International, 2002; method 972.16]. Milk fat and protein yield $(\mathrm{kg} / \mathrm{d})$ were calculated for the 5-d collection period, based on the product of the milk production yield and milk composition at each milking on those days. Fat-corrected milk yield was calculated as follows: FCM yield $=0.399 \times$ [milk yield $(\mathrm{kg} / \mathrm{d})]+15.02 \times$ [fat yield $(\mathrm{kg} / \mathrm{d})]($ Sadri et al., 2009). Furthermore, fat- and protein-corrected milk (FPCM) was computed according to following formula: $\mathrm{FPCM}$ yield $=(0.337+0.116 \times$ fat $\%+0.06$ $\times$ protein $\%) \times$ milk yield $(\mathrm{kg} / \mathrm{d})$ (Sterk et al., 2011). Feed efficiency was calculated either as kilograms of actual milk per kilogram of DMI or as kilograms of $4 \%$ FCM per kilogram of DMI.

\section{Statistical Analyses}

Data were summarized by period and analyzed using PROC MIXED of SAS (SAS Institute, 2003) to 
account for the effects of square, period within square, cow within square, and treatments. The model included the fixed effects of square, period within square, and treatment. Cow within square was the specified term for the random effect. The REML method was used to estimate least squares means, and the Kenward-Roger method was used to calculate denominator degrees of freedom. The effect of square was not significant and did not influence the results. Normality of distribution and homogeneity of variance for residuals were tested using PROC UNIVARIATE (SAS Institute, 2003). Polynomial analysis also was tested to determine the linear or quadratic response to increasing corn grain to barley grain ratio using PROC MIXED of SAS (SAS Institute, 2003). Furthermore, data for particle size distribution, pef, and peNDF of TMR were averaged by period and analyzed by including treatment as fixed effect and period as a random effect. Effects of the factors were declared significant at $P \leq 0.05$, unless otherwise noted, and trends were discussed at $P \leq 0.10$.

\section{RESULTS AND DISCUSSION}

\section{Diet Characteristics and Particle Size Distribution}

The ingredient composition and chemical analysis of experimental TMR are presented in Table 1. Across diets, the DM, OM, CP, NFC, NDF, EE, and ash concentrations (mean $\pm \mathrm{SE}$ ) were $54.0 \pm 0.2,49.1 \pm 0.2$, $17.5 \pm 0.3,39.0 \pm 0.7,30.2 \pm 0.9,4.2 \pm 0.5$, and $9.0 \pm$ $0.2 \%$ (DM basis), respectively. Numerically lower NFC and EE, and also greater NDF concentrations of the barley- compared with corn-based diets is a reflection of differences in those component concentrations of the original cereal grains. It is noteworthy that numerically lower NFC or greater NDF concentration of the BBD did not compromise production performance when compared with CBD (Sadri et al., 2009; Kargar et al., 2013). Average dietary NDF concentration was on the high end of the NRC (2001) minimum recommendations of 25 to $33 \%$, for maintaining suitable ruminal function.

Data on particle size distribution of forages (including corn silage and alfalfa hay) and TMR are presented in Table 2. The proportion of the particles retained on the top sieve of the PSPS $(>19 \mathrm{~mm})$ did not differ among treatments and averaged $10.3 \%$ of DM. The percentage of particles retained on the second sieve (8-19 mm) increased quadratically as the amount of corn grain increased in the diets and it was greater $(P<0.001)$ for $\mathrm{CBD}$ than for $\mathrm{BBD}$ and $\mathrm{BCBD}$ diets, resulting in greater $\operatorname{pef}_{>8}(P=0.005)$. However, $\operatorname{peNDF}_{>8}$ was not different between $\mathrm{CBD}$ and BBD diets, although it was greater $(P=0.03)$ in $\mathrm{CBD}$ compared with $\mathrm{BCBD}$
(11.1 vs. 9.7\%). Similar to results reported by Nasrollahi et al. (2012), the percentage of the particles with an average size of 1.18 to $8 \mathrm{~mm}$ was greater in the BBD compared with corn grain-containing diets, resulting in greater $\operatorname{pef}_{>1.18}(P=0.02)$ and $\operatorname{peNDF}_{>1.18}$ $(P<0.001)$. As reported by Nasrollahi et al. $(2012)$, the feed materials retained on the bottom pan $(<1.18$ $\mathrm{mm}$ ) increased quadratically as the amount of corn grain increased in the diets and it was greater in BCBD and $\mathrm{CBD}$ relative to $\mathrm{BBD}$. In our experiment, soybean meal and canola meal were used as intact forms and not processed further to equalize their particle size before using in concentrate mixtures. However, the proportion of pelleted canola meal retained on the 8-mm sieve was more than that of soybean meal. In addition, Nasrollahi et al. (2012) reported similar results in diets (based on both barley and 50:50 barley and corn grains) containing equal proportions of soybean meal and canola meal with the same particle size. This probably shows that the barley and corn grains responded differently to grinding, although milling conditions were similar for both. Although we did not measure grain particle size distribution in this experiment, differences in grain particle size during grinding to a similar size might have been caused by differences in physical texture and density (Nasrollahi et al., 2012; Kargar et al., 2013). However, geometric mean particle sizes were not different among the diets at $4.3 \mathrm{~mm}$.

\section{Milk Yield and Milk Composition}

Although actual, 4\% FCM, and FPCM yields were not different across treatment diets, FPCM yield increased quadratically as the amount of corn grain increased in the diets $(P=0.08$; Table 3$)$. Overton et al. (1995) and Khorasani et al. (2001) observed a quadratic response in milk yield as result of substituting barley grain with corn grain. They observed that cows produced greatest milk when fed diets containing corn and barley grains in ratios of 100:0 and 50:50 but milk yield decreased when this ratio was 0:100. The shift in the site of starch digestion from the rumen to the intestine has been proposed to increase the availability of glucose for lactose synthesis, which might have been responsible for the increased milk yield of cows fed CBD (McCarthy et al., 1989; Overton et al., 1995; Khorasani et al., 2001). It has been reported that not net increase in glucose entry to the portal vein occurred when the amount of starch passage to the small intestine was enhanced (Nocek and Tamminga, 1991). However, Nocek and Tamminga (1991) hypothesized that absorption of glucose derived from the hydrolysis of starch in the small intestine may spare glucose derived from gluconeogenesis for gut metabolism, which may indirectly increase the amount of 
Table 2. Physical characteristics of corn silage, alfalfa hay, and dietary treatments measured using the Penn State Particle Separator ${ }^{1}$

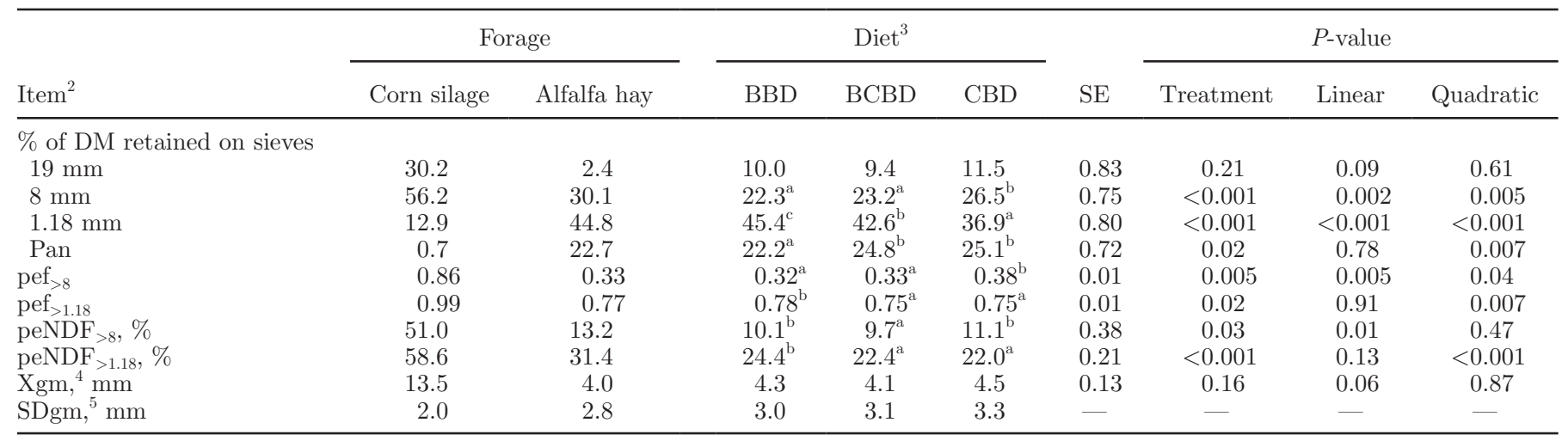

${ }^{a-c}$ Means within a row with different superscripts differ $(P<0.05)$.

${ }^{1}$ Particle length variables were measured using the Penn State Particle Separator (The Pennsylvania State University, University Park; Kononoff et al., 2003).

${ }^{2}$ pef $_{>8}$ and pef $_{>1.18}=$ physical effectiveness factor , determined as the proportion of particles retained on 2 sieves (Lammers et al., 1996) and on 3 sieves (Kononoff et al., 2003), respectively; peNDF $>8$ and peNDF $>1.18=$ physically effective NDF, determined as NDF content of TMR multiplied by pef $>8$ and pef $_{>1.18}$, respectively.

${ }^{3} \mathrm{BBD}=$ barley-based diet; $\mathrm{BCBD}=$ barley- and corn-based diet; $\mathrm{CBD}=$ corn-based diet.

${ }^{4}$ Geometric mean particle size, calculated according to the method of the American Society of Agricultural Engineers (ASAE, 1995; method S424.1).

${ }^{5}$ Geometric SD of particle size, calculated according to the method of the American Society of Agricultural Engineers (ASAE, 1995; method S424.1).

glucose that can be directed to the mammary gland. A tendency to quadratic increase in milk yield can probably be attributed to the numerical increase in DMI $(0.5 \mathrm{~kg} / \mathrm{d})$ of cows fed CBD. However, the effect of numerically lesser intake in cows fed BBD versus CBD on milk yield was compensated by a significant increase (73.5 vs. $69.1 \%)$ in $\mathrm{OM}$ digestibility of $\mathrm{BBD}$ versus CBD (Kargar et al., 2014) and thereby neutralized the treatment effect on milk yield.
Milk fat percentage increased linearly with increasing amount of the corn grain in the diets and it was greater in CBD relative to BCBD but not BBD. However, milk fat yield tended to show a linear increase as the amount of corn grain included in the diets increased. In contrast to our results, Khorasani et al. (2001) did not observe any change in milk fat percentage and yield by feeding 3 different ratios of barley grain to corn grain to Holstein dairy cows. Furthermore, Overton et al.

Table 3. Milk yield, milk composition and feed efficiency as influenced by substituting barley grain with corn grain

\begin{tabular}{|c|c|c|c|c|c|c|c|}
\hline \multirow[b]{2}{*}{ Item } & \multicolumn{3}{|c|}{$\operatorname{Diet}^{1}$} & \multirow[b]{2}{*}{ SE } & \multicolumn{3}{|c|}{$P$-value } \\
\hline & $\mathrm{BBD}$ & $\mathrm{BCBD}$ & CBD & & Treatment & Linear & Quadratic \\
\hline \multicolumn{8}{|l|}{ Yield, $\mathrm{kg} / \mathrm{d}$} \\
\hline Actual milk & 48.0 & 49.3 & 48.6 & 1.27 & 0.51 & 0.53 & 0.32 \\
\hline $4 \% \mathrm{FCM}^{2}$ & 35.7 & 36.6 & 38.1 & 1.23 & 0.13 & 0.21 & 0.11 \\
\hline $\mathrm{FPCM}^{3}$ & 37.0 & 38.1 & 39.1 & 1.11 & 0.14 & 0.31 & 0.08 \\
\hline Fat & 1.102 & 1.124 & 1.242 & 0.063 & 0.07 & 0.07 & 0.14 \\
\hline Protein & 1.341 & 1.398 & 1.382 & 0.043 & 0.36 & 0.69 & 0.17 \\
\hline \multicolumn{8}{|l|}{ Composition, $\%$} \\
\hline Fat & $2.31^{\mathrm{ab}}$ & $2.28^{\mathrm{a}}$ & $2.57^{\mathrm{b}}$ & 0.12 & 0.03 & 0.02 & 0.25 \\
\hline Protein & 2.81 & 2.84 & 2.84 & 0.06 & 0.75 & 0.86 & 0.47 \\
\hline \multicolumn{8}{|l|}{ Feed efficiency } \\
\hline Milk yield/DMI & 1.93 & 1.94 & 1.90 & 0.05 & 0.83 & 0.57 & 0.87 \\
\hline $\mathrm{FCM} / \mathrm{DMI}$ & 1.43 & 1.43 & 1.48 & 0.04 & 0.56 & 0.37 & 0.58 \\
\hline
\end{tabular}

${ }_{\mathrm{a}, \mathrm{b}}$ Means within a row with different superscripts differ $(P<0.05)$.

${ }^{1} \mathrm{BBD}=$ barley-based diet; $\mathrm{BCBD}=$ barley- and corn-based diet; $\mathrm{CBD}=$ corn-based diet.

${ }^{2} \mathrm{FCM}$ yield $=0.399 \times[$ milk yield $(\mathrm{kg} / \mathrm{d})]+15.02 \times[$ fat yield $(\mathrm{kg} / \mathrm{d})]($ Sadri et al., 2009) .

${ }^{3} \mathrm{FPCM}$ yield $=$ fat- and protein-corrected milk $[(0.337+0.116 \times$ fat $\%+0.06 \times$ protein $\%) \times$ milk yield

$(\mathrm{kg} / \mathrm{d})]$ (Sterk et al., 2011). 
(1995) reported that milk fat percentage was affected quadratically by the proportion of barley grain and corn grain in the diets, such that the percentage of fat was greatest when diets contained barley grain and corn grain in ratios of 100:0 and 0:100. Accordingly, the percentages of fat in milk were lowest when blends of barley grain and corn grain were fed to cows, as observed in cows fed BCBD in the current experiment. Overton et al. (1995) attributed this effect to the reduced acetate-to-propionate ratio when barley grain was substituted with corn grain in the diet. However, in the current experiment, the acetate-to-propionate ratio (2.40) was not different across treatments. Lesser milk fat percentage for the BCBD relative to $\mathrm{CBD}$ may be, in part, explained by a tendency for lesser intake of long particles and EE and numerically greater milk yield as well. All diets caused low milk fat yield, most likely because of the presence of PUFA in fish oil (a source of eicosapentaenoic acid and docosahexaenoic acid) and soybean oil (a source of linoleic acid), which are known to alter ruminal biohydrogenation intermediates and reduce mammary gland lipogenesis (Alizadeh et al., 2012; Kargar et al., 2012, 2013). This decrease was likely not due to insufficient dietary forage NDF or short particle size of alfalfa hay (Kargar et al., 2013). The recommended minimum concentration (\% of DM) of forage NDF for a given TMR diet (a minimum NDF of $29 \%$ and a maximum NFC of $40 \%$ ) is $17 \%$ (NRC, 2001). In the current experiment, this value was within that range and equaled $20 \%$ of dietary DM. The proportions of particles retained on the 8-mm sieve $(24.0 \%)$ and in the pan $(22.9 \%)$ were lower $(40 \pm 10 \%)$ and greater $(<20 \%)$, respectively, than ranges reported by others (Heinrichs and Kononoff, 2002). This indicates increased intake of easily degradable carbohydrates and thereby may have caused a shift in VFA production pattern toward propionate. This could limit the amount of acetate and butyrate available for de novo synthesis of FA in the mammary gland (Grant et al., 1990; Ashes et al., 1997). However, in the current experiment, molar concentrations of rumen VFA, including acetate $(61.7 \mathrm{mM})$, propionate $(25.5 \mathrm{mM})$, and butyrate $(13.3 \mathrm{mM})$, were not affected by dietary treatments. Tafaj et al. (2007), in a metaanalysis, reported that forage particle size does not correlate with milk yield and milk fat yield, which indicates complexity in nutritional effects of dietary particle size and peNDF.

As reported by Khorasani et al. (2001), milk protein percentage and yield were not affected by the substitution of barley grain with corn grain. Lack of difference for milk protein yield among BBD and CBD may imply that type of grain (barley vs. corn) had little effect on rumen microbial protein yield and also intestinal amino acid availability, and thereby that amino acid delivery to the mammary gland was not influenced (Sadri et al., 2009). However, Overton et al. (1995) reported that both milk protein percentage and yield linearly increased and decreased, respectively, as the proportions of barley grain increased in the diets. Feed intake and lactational responses might be influenced by the given source of protein supplement; however, McCarthy et al. (1989) and Casper et al. (1999) reported that substitution of 2 different dietary protein supplements in BBD versus CBD resulted in similar DMI, milk yield, and ruminal fermentation parameters. More recently, Maxin et al. (2013) replaced canola meal for soybean meal in dairy cow diets and observed no change in nutrient intake, milk yield, and milk composition. Therefore, it is unlikely that our results are influenced significantly by changing additional elements of the diets. Efficiency for milk yield, defined either as milk yield per DMI or as $4 \%$ FCM per DMI was similar among treatment diets at 1.92 and 1.45 , respectively.

\section{Sorting Behavior}

Substitution of barley grain with corn grain did not affect sorting activity, which is expressed as the sorting index (Table 4). Inconsistent with our results, Silveira et al. (2007) reported that cows fed CBD sorted for longer particles $(>19 \mathrm{~mm})$ and against medium-length particles on the second sieve of the PSPS to a greater extent than cows fed BBD. Regardless of the kind of dietary treatment fed, cows sorted, to a similar extent, against long particles $(>19 \mathrm{~mm})$. This result is not unexpected, as most investigations of feed sorting have conveyed that cattle sort widely against long particles, regardless of the substrate making up the bulk of the long-particle fraction (Leonardi and Armentano, 2003; Kargar et al., 2013). Dietary treatments did not affect intake of particles retained on the $19-\mathrm{mm}$ sieve. However, intake of particles retained on the $19-\mathrm{mm}$ sieve tended $(P=0.06)$ to increase linearly with increasing amount of corn grain in the diets. Corresponding to differences in the profile of particles of dietary treatments (Table 2), intakes of particles retained on the $8 \mathrm{~mm}$ sieve and in the pan increased quadratically and were greater in $\mathrm{CBD}$ than in $\mathrm{BBD}$ and $\mathrm{BCBD}$. However, intake of particles retained on the $1.18 \mathrm{~mm}$ sieve showed a quadratic increase so that it was greater in BBD and BCBD compared with CBD.

\section{Nutrient Intake}

Intakes of nutrients (other than EE and peNDF $_{>8}$ ) were not different across dietary treatments (Table 5). In the current experiment, average DMI was $25.6 \mathrm{~kg} / \mathrm{d}$, 
Table 4. Sorting index and particle size intake of lactating dairy cows as influenced by substituting barley grain with corn grain

\begin{tabular}{|c|c|c|c|c|c|c|c|}
\hline \multirow[b]{2}{*}{ Item } & \multicolumn{3}{|c|}{$\operatorname{Diet}^{1}$} & \multirow[b]{2}{*}{$\mathrm{SE}$} & \multicolumn{3}{|c|}{$P$-value } \\
\hline & $\mathrm{BBD}$ & $\mathrm{BCBD}$ & $\mathrm{CBD}$ & & Treatment & Linear & Quadratic \\
\hline \multicolumn{8}{|c|}{ Sorting index, ${ }^{2} \%$} \\
\hline 19 & 94.1 & 88.0 & 92.7 & 3.60 & 0.34 & 0.28 & 0.31 \\
\hline 8 & 100.7 & 100.8 & 101.7 & 0.62 & 0.22 & 0.17 & 0.27 \\
\hline 1.18 & 101.1 & 101.7 & 100.8 & 0.78 & 0.50 & 0.25 & 0.84 \\
\hline Pan & 101.3 & 102.0 & 101.4 & 0.89 & 0.66 & 0.45 & 0.60 \\
\hline \multicolumn{8}{|c|}{ DMI, $\mathrm{kg} / \mathrm{d}$} \\
\hline 19 & 2.5 & 2.4 & 3.0 & 0.26 & 0.14 & 0.06 & 0.50 \\
\hline 8 & $5.6^{\mathrm{a}}$ & $5.9^{\mathrm{a}}$ & $6.8^{\mathrm{b}}$ & 0.28 & $<0.001$ & 0.003 & 0.001 \\
\hline 1.18 & $11.5^{\mathrm{b}}$ & $10.9^{\mathrm{b}}$ & $9.5^{\mathrm{a}}$ & 0.28 & $<0.001$ & 0.003 & 0.002 \\
\hline Pan & $5.6^{\mathrm{a}}$ & $6.4^{\mathrm{ab}}$ & $6.5^{\mathrm{b}}$ & 0.24 & 0.04 & 0.73 & 0.01 \\
\hline
\end{tabular}

${ }_{\mathrm{a}, \mathrm{b}}$ Means within a row with different superscripts differ $(P<0.05)$.

${ }^{1} \mathrm{BBD}=$ barley-based diet; $\mathrm{BCBD}=$ barley- and corn-based diet; $\mathrm{CBD}=$ corn-based diet.

${ }^{2}$ Sorting index $>100$ indicates sorting for particles and $<100$ indicates sorting against particles (Leonardi and Armentano, 2003).

or approximately $3.8 \%$ of mean BW, which was within the expected range for dairy cows producing more than $35 \mathrm{~kg}$ of milk/d (NRC, 2001). With diets based on highly fermentable grain in the rumen, such as barley, an increase in acid load and thereby a decrease in rumen $\mathrm{pH}$ may decrease microbial growth and DMI when ensiled forages are the main type of dietary forage (Reynolds, 2006). It seems unlikely that this occurred in the present experiment, as half of the dietary forage came from alfalfa hay and mean rumen $\mathrm{pH}$ (6.13) and total VFA concentrations $(103.9 \mathrm{mM})$ were not different among treatments. Substitution of barley grain for corn grain in dairy cow diets with alfalfa hay and cotton seed hulls as forage types tended to increase DMI and fiber digestion (Reynolds, 2006). Due to greater EE concentration of corn grain relative to barley grain, intake of EE increased linearly with increasing inclusion rate of corn grain in the diets $(P<0.001)$. Furthermore, cows fed $\mathrm{BBD}$ and $\mathrm{BCBD}$ ate less peNDF ${ }_{>8}$ compared with cows fed $\operatorname{CBD}(P=0.01)$. However, cows fed BBD tended to increase peNDF $>1.18$ intake relative to cows fed BCBD $(P=0.07)$ and $\mathrm{CBD}(P=0.06)$.

\section{Meal and Rumination Patterns}

Eating patterns were not affected by dietary treatments. The number of eating bouts per day, meal length, and eating rate were not different among treatments $(P$ $>0.05$; Table 6 ) and correspond with no difference in DMI across treatments (Table 5). This is similar to our previous work where meal size and intermeal interval, and thereby DMI, were not different for diets containing barley grain or corn grain (Kargar et al., 2013). In contrast, Oba and Allen (2003) reported that a more rapidly fermented starch source (high-moisture corn grain vs. corn grain) reduced meal size by $21 \%$ and decreased intermeal interval by $12 \%$, resulting in an $8 \%$ reduction in DMI. This suggests that eating patterns of lactating dairy cows are not affected by the type of starch in their diet.

Table 5. Intake of nutrients as influenced by substituting barley grain with corn grain

\begin{tabular}{|c|c|c|c|c|c|c|c|}
\hline \multirow[b]{2}{*}{ Intake, $\mathrm{kg} / \mathrm{d}$} & \multicolumn{3}{|c|}{ Diet $^{1}$} & \multirow[b]{2}{*}{$\mathrm{SE}$} & \multicolumn{3}{|c|}{$P$-value } \\
\hline & $\mathrm{BBD}$ & $\mathrm{BCBD}$ & CBD & & Treatment & Linear & Quadratic \\
\hline $\mathrm{DM}$ & 25.3 & 25.7 & 25.9 & 0.67 & 0.66 & 0.79 & 0.39 \\
\hline $\mathrm{OM}$ & 23.1 & 23.4 & 23.6 & 0.61 & 0.70 & 0.79 & 0.43 \\
\hline $\mathrm{CP}$ & 4.5 & 4.5 & 4.6 & 0.13 & 0.92 & 0.75 & 0.82 \\
\hline $\mathrm{NFC}$ & 9.9 & 10.4 & 10.4 & 0.24 & 0.16 & 0.75 & 0.06 \\
\hline NDF & 7.7 & 7.4 & 7.4 & 0.21 & 0.37 & 0.99 & 0.17 \\
\hline Forage NDF & 5.1 & 5.2 & 5.2 & 0.13 & 0.65 & 0.79 & 0.38 \\
\hline Ether extract & $0.977^{\mathrm{a}}$ & $1.077^{\mathrm{b}}$ & $1.216^{\mathrm{c}}$ & 0.038 & $<0.001$ & 0.001 & $<0.001$ \\
\hline $\operatorname{peNDF}_{>8}^{2}$ & $2.4^{\mathrm{a}}$ & $2.4^{\mathrm{a}}$ & $2.8^{\mathrm{b}}$ & 0.14 & 0.01 & 0.009 & 0.08 \\
\hline $\operatorname{peNDF}_{>1.18^{2}}^{2}$ & 5.9 & 5.7 & 5.6 & 0.17 & 0.16 & 0.68 & 0.06 \\
\hline
\end{tabular}

${ }^{\mathrm{a}-\mathrm{c}}$ Means within a same row with different superscripts differ $(P<0.05)$.

${ }^{1} \mathrm{BBD}=$ barley-based diet; $\mathrm{BCBD}=$ barley- and corn-based diet; $\mathrm{CBD}=$ corn-based diet.

${ }^{2}$ peNDF $=$ physically effective $\mathrm{NDF}$ of $2\left(\mathrm{peNDF}_{>8}\right)$ and 3 sieves $\left(\mathrm{peNDF}_{>1.18}\right)$, respectively. 
Table 6. Meal patterns of lactating dairy cows as influenced by substituting barley grain with corn grain

\begin{tabular}{|c|c|c|c|c|c|c|c|}
\hline \multirow[b]{2}{*}{ Item } & \multicolumn{3}{|c|}{ Diet $^{1}$} & \multirow[b]{2}{*}{$\mathrm{SE}$} & \multicolumn{3}{|c|}{$P$-value } \\
\hline & BBD & $\mathrm{BCBD}$ & CBD & & Treat & Linear & Quadratic \\
\hline \multicolumn{8}{|l|}{ Meals } \\
\hline Bouts/d & 17 & 19 & 17 & 1.62 & 0.58 & 0.34 & 0.68 \\
\hline Length, $\min /$ meal & 18 & 17 & 18 & 1.40 & 0.78 & 0.52 & 0.77 \\
\hline Interval, min & 69 & 69 & 73 & 5.93 & 0.78 & 0.57 & 0.69 \\
\hline Eating rate, $\mathrm{kg}$ of $\mathrm{DM} / \mathrm{min}$ & 0.088 & 0.089 & 0.091 & 0.004 & 0.87 & 0.72 & 0.70 \\
\hline Meal size, $\mathrm{kg}$ of $\mathrm{DM}$ & 1.55 & 1.47 & 1.62 & 0.13 & 0.60 & 0.32 & 0.99 \\
\hline \multicolumn{8}{|l|}{ Rumination } \\
\hline Bouts/d & 12 & 13 & 13 & 0.80 & 0.49 & 0.43 & 0.36 \\
\hline Bout length, $\min /$ meal & 40 & 35 & 37 & 2.63 & 0.49 & 0.58 & 0.29 \\
\hline Bout interval, min & 76 & 71 & 81 & 7.81 & 0.29 & 0.12 & 0.96 \\
\hline
\end{tabular}

${ }^{1} \mathrm{BBD}=$ barley-based diet; $\mathrm{BCBD}=$ barley- and corn-based diet; $\mathrm{CBD}=$ corn-based diet.

Rumination patterns were not different among treatments. The number of ruminating bouts per day, bout length, and interval between bouts were not affected by dietary treatments $(P>0.05$; Table 6$)$ and correspond with no difference in rumination time across treatments (Table 7). This is inconsistent with our previous work (Kargar et al., 2013) and others (Beauchemin and Rode, 1997) where a greater bout length and thereby a greater rumination time were observed for BBD versus CBD fed to dairy cows. This may imply that ruminating patterns of lactating dairy cows are not influenced by the type of grain differing in expected ruminal fermentability.

\section{Chewing Activity}

Consistent with others (Beauchemin and Rode, 1997; Oba and Allen, 2003; Kargar et al., 2013), time spent eating was not affected by the dietary treatments (Table 7). Nasrollahi et al. (2012) reported that, due to greater DMI, cows fed a 50:50 blend of barley grain and corn grain spent more time eating than cows fed

Table 7. Chewing activities of lactating dairy cows as influenced by substituting barley grain with corn grain

\begin{tabular}{|c|c|c|c|c|c|c|c|}
\hline \multirow[b]{2}{*}{ Item } & \multicolumn{3}{|c|}{$\operatorname{Diet}^{1}$} & \multirow[b]{2}{*}{ SE } & \multicolumn{3}{|c|}{$P$-value } \\
\hline & $\mathrm{BBD}$ & BCBD & $\mathrm{CBD}$ & & Treatment & Linear & Quadratic \\
\hline \multicolumn{8}{|l|}{ Eating time } \\
\hline $\min / \mathrm{d}$ & 293 & 295 & 291 & 11.11 & 0.94 & 0.74 & 0.98 \\
\hline $\min /$ bout & 18 & 17 & 18 & 1.39 & 0.78 & 0.54 & 0.75 \\
\hline $\min / \mathrm{kg}$ of DMI & 11.7 & 11.6 & 11.4 & 0.57 & 0.90 & 0.84 & 0.70 \\
\hline $\mathrm{min} / \mathrm{kg}$ of NDF intake & 38.7 & 40.2 & 40.0 & 2.01 & 0.82 & 0.96 & 0.54 \\
\hline $\mathrm{min} / \mathrm{kg}$ of forage NDF intake & 58.7 & 57.7 & 57.0 & 2.84 & 0.89 & 0.84 & 0.68 \\
\hline $\mathrm{min} / \mathrm{kg}$ of $\mathrm{peNDF}_{>8}{ }^{4}$ & 125.3 & 130.2 & 110.7 & 7.17 & 0.09 & 0.04 & 0.52 \\
\hline $\mathrm{min} / \mathrm{kg}$ of $\mathrm{peNDF}_{>1.18}{ }^{4}$ & 50.2 & 54.0 & 53.8 & 2.60 & 0.45 & 0.94 & 0.21 \\
\hline \multicolumn{8}{|l|}{ Ruminating time } \\
\hline $\min / \mathrm{d}$ & 473 & 462 & 439 & 22.50 & 0.50 & 0.45 & 0.38 \\
\hline $\min /$ bout & 40 & 35 & 37 & 2.63 & 0.52 & 0.59 & 0.31 \\
\hline $\mathrm{min} / \mathrm{kg}$ of $\mathrm{DMI}$ & 18.9 & 18.0 & 17.1 & 1.02 & 0.34 & 0.48 & 0.20 \\
\hline $\mathrm{min} / \mathrm{kg}$ of NDF intake & 62.4 & 62.5 & 60.1 & 3.54 & 0.78 & 0.54 & 0.75 \\
\hline $\mathrm{min} / \mathrm{kg}$ of forage NDF intake & 94.5 & 89.8 & 85.5 & 5.13 & 0.32 & 0.47 & 0.19 \\
\hline $\mathrm{min} / \mathrm{kg}$ of $\mathrm{peNDF}_{>8}$ & $203.3^{\mathrm{b}}$ & $203.6^{\mathrm{b}}$ & $165.6^{\mathrm{a}}$ & 13.18 & 0.02 & 0.01 & 0.13 \\
\hline $\mathrm{min} / \mathrm{kg}$ of $\mathrm{peNDF}{ }_{>1.18}$ & 80.9 & 84.1 & 80.8 & 4.59 & 0.75 & 0.50 & 0.72 \\
\hline \multicolumn{8}{|l|}{ Total chewing time } \\
\hline $\min / \mathrm{d}$ & 766 & 756 & 730 & 29.96 & 0.57 & 0.46 & 0.45 \\
\hline $\mathrm{min} /$ bout & 47 & 44 & 45 & 3.52 & 0.77 & 0.73 & 0.53 \\
\hline $\mathrm{min} / \mathrm{kg}$ of $\mathrm{DMI}$ & 30.3 & 29.3 & 28.4 & 1.46 & 0.51 & 0.60 & 0.31 \\
\hline $\mathrm{min} / \mathrm{kg}$ of NDF intake & 100.9 & 102.6 & 100.0 & 5.17 & 0.89 & 0.65 & 0.93 \\
\hline $\min / \mathrm{kg}$ of forage NDF intake & 153.0 & 147.1 & 142.3 & 7.39 & 0.43 & 0.56 & 0.26 \\
\hline $\mathrm{min} / \mathrm{kg}$ of $\mathrm{peNDF}_{>8}$ & $328.4^{\mathrm{b}}$ & $333.2^{\mathrm{b}}$ & $276.0^{\mathrm{a}}$ & 19.39 & 0.02 & 0.01 & 0.19 \\
\hline $\mathrm{min} / \mathrm{kg}$ of $\mathrm{peNDF}_{>1.18}$ & 131.0 & 137.7 & 134.5 & 6.74 & 0.63 & 0.65 & 0.41 \\
\hline Resting, $\mathrm{min} / \mathrm{d}$ & 674 & 684 & 710 & 29.96 & 0.57 & 0.46 & 0.45 \\
\hline
\end{tabular}

${ }^{\mathrm{a}, \mathrm{b}}$ Means within a row with different superscripts differ $(P<0.05)$.

${ }^{1} \mathrm{BBD}=$ barley-based diet; $\mathrm{BCBD}=$ barley- and corn-based diet; $\mathrm{CBD}=$ corn-based diet.

${ }^{4}$ peNDF $=$ physically effective $\mathrm{NDF}$ of $2\left(\mathrm{peNDF}_{>8}\right)$ and 3 sieves $\left(\mathrm{peNDF}_{>1.18}\right)$, respectively. 
BBD (228 vs. $213 \mathrm{~min} / \mathrm{d}$ ). However, in the current experiment, DMI was not different between BBD and BCBD. Furthermore, characteristics of eating behavior are influenced mainly by physical factors that affect ease of ingestion and mastication (Beauchemin, 1991). Thus, all diets were apparently consumed with similar ease, as forage-to-concentrate ratio, forage NDF concentration, and geometric mean particle size were not different among diets. However, eating time, when expressed as minutes per unit of $\mathrm{peNDF}_{>8}$ intake, decreased linearly as the amount of corn grain inclusion in the diets increased. Because daily eating time was not different among diets, a tendency $(P=0.09)$ for greater daily eating time per unit of peNDF ${ }_{>8}$ in BCBD than in $\mathrm{CBD}$ can be attributed to lower peNDF $\mathrm{N}_{>8}$ intake.

Time spent ruminating was not affected by the treatment diets, although it was numerically greater for cows fed BBD than for cows fed CBD by 34 min (Table 7), which is in line with Oba and Allen (2003) but not Beauchemin and Rode (1997) and Kargar et al. (2013), who observed that cows fed BBD spent more time for rumination, which was a result of more rumination periods of longer duration, compared with cows fed CBD. It seems that in the current experiment, forage NDF concentration and intake across diets was enough to promote chewing, salivation, and high rumen $\mathrm{pH}$, which may have masked some effects caused by differences in fermentability of diets in the rumen (Mertens, 1997). Rumination time, when expressed as minutes per unit of peNDF $>8$ intake was greater $(P=0.02)$ in $\mathrm{BBD}$ and $\mathrm{BCBD}$ than in $\mathrm{CBD}$, resulting in greater total chewing time per unit of $\operatorname{peNDF}_{>8}$ intake $(P=0.02)$. As observed for time spent ruminating, total chewing time was not different across treatments but was numerically greater in BBD than in CBD by 36 min.

\section{CONCLUSIONS}

Changing diet fermentability by the substitution of barley grain with corn grain affected neither meal size nor intermeal interval and thereby feed intake and milk yield remained similar across treatments. Changing barley grain-to-corn grain ratio in the oil-supplemented diets had minimal effect on feeding and chewing behavior and lactational performance of Holstein dairy cows.

\section{ACKNOWLEDGMENTS}

This manuscript is contribution no. 90000943 from the Iran National Science Foundation (Tehran, Iran). The authors thank the Isfahan University of Technology (IUT; Isfahan, Iran) for partially funding this research and especially for providing suitable experimental conditions. The authors express their kind appreciation to the farm staff at Lavark, the farm animal research and teaching unit (IUT), for diligent animal care; to Mohsen Babashahi, Mojtaba Arjmandfar, Farzad Hashemzadeh-Cigari, Azizollah Bakhtari, Ebrahim Ghasemi, Sayed M. Nasrollahi, Hamed Beiranvand, Heshmat Bahrami-Yekdangi, Ali Kahyani, Mahdi Saebi, Mohammad Golkar, and Hamid Khoshouei (IUT), and Ehsan Kamalian (Gorgan University of Agricultural Sciences and Natural Resources, Gorgan, Iran) for their help in conducting this experiment; to Ali Daroodi (Pars Kilka Co., Mazandaran, Iran) for providing fish oil; to Toghrol Lotfipour (Nahan Gol Industrial Group, Boroujen, Iran) for his helpful assistance in laboratory analyses; and to several students from the IUT completing course requirements for their input on the research and laboratory analyses.

\section{REFERENCES}

Alizadeh, A. R., M. Alikhani, G. R. Ghorbani, H. R. Rahmani, L. Rashidi, and J. J. Loor. 2012. Effects of feeding roasted safflower seeds (variety IL-111) and fish oil on dry matter intake, performance and milk fatty acid profiles in dairy cattle. J. Anim. Physiol. Anim. Nutr. (Berl.) 96:466-473.

Allen, M. S. 2000. Effects of diet on short-term regulation of feed intake by lactating dairy cattle. J. Dairy Sci. 83:1598-1624.

AOAC International. 2002. Official Methods of Analysis. 17th ed. AOAC International, Arlington, VA.

ASAE (American Society of Agricultural Engineers). 1995. Method of determining and expressing fineness of feed material by sieving. Method S424.1. Page 461 in ASAE Standards 1995. ASAE, St. Joseph, MI.

Ashes, J. R., S. K. Gulati, and T. W. Scott. 1997. Potential to alter the content and composition of milk fat through nutrition. J. Dairy Sci. 80:2204-2212.

Beauchemin, K. A. 1991. Effects of dietary neutral detergent fiber concentration and alfalfa hay quality on chewing, rumen function, and milk production of dairy cows. J. Dairy Sci. 74:3140-3151.

Beauchemin, K. A., and L. M. Rode. 1997. Minimum versus optimum concentrations of fiber in dairy cow diets based on barley silage and concentrates of barley or corn. J. Dairy Sci. 80:1629-1639.

Beauchemin, K. A., and W. Z. Yang. 2006. The pros and cons of enhancing ruminal digestion of starch in dairy cow diets. Pages 45-54 in Proc. 41th Annual Pacific Northwest Anim. Nutr. Conf. Vancouver, BC, Canada.

Casper, D. P., H. A. Maiga, M. J. Brouk, and D. J. Schingoethe. 1999. Synchronization of carbohydrate and protein sources on fermentation and passage rates in dairy cows. J. Dairy Sci. 82:1779-1790.

Grant, R. J., V. F. Colenbrander, and D. R. Mertens. 1990. Milk fat depression in dairy cows: Role of particle size of alfalfa hay. J. Dairy Sci. 73:1823-1833.

Heinrichs, J. and P. Kononoff. 2002. Evaluating particle size of forages and TMRs using the new Penn State Forage Particle Separator. Technical Bulletin of The Pennsylvania State University, College of Agriculture Science, Cooperative Extension: DAS 02-42. Department of Dairy and Animal Science, The Pennsylvania State University, University Park.

Kargar, S., G. R. Ghorbani, M. Alikhani, M. Khorvash, L. Rashidi, and D. J. Schingoethe. 2012. Lactational performance and milk fatty acid profile of Holstein cows in response to dietary fat supplements and forage:concentrate ratio. Livest. Sci. 150:274-283.

Kargar, S., G. R. Ghorbani, and M. Khorvash. 2014. Nutrient digestibility, rumen fermentation parameters, and production performance in response to changing dietary ratio of barley to corn grain of Holstein dairy cows. J. Rumin. Res. 2:1-16. (In Persian). 
Kargar, S., G. R. Ghorbani, M. Khorvash, E. Kamalian, and D. J. Schingoethe. 2013. Dietary grain source and oil supplement: Feeding behavior and lactational performance of Holstein cows. Livest. Sci. 157:162-172.

Kargar, S., M. Khorvash, G. R. Ghorbani, M. Alikhani, and W. Z. Yang. 2010. Short communication: Effects of dietary fat supplements and forage:concentrate ratio on feed intake, feeding, and chewing behavior of Holstein dairy cows. J. Dairy Sci. 93:42974301.

Khorasani, G. R., E. K. Okine, and J. J. Kennelly. 2001. Effects of substituting barley grain with corn on ruminal fermentation characteristics, milk yield, and milk composition of Holstein cows. J. Dairy Sci. 84:2760-2769.

Kononoff, P. J., A. J. Heinrichs, and D. R. Buckmaster. 2003. Modification of the Penn State forage and total mixed ration particle separator and the effects of moisture content on its measurements. J. Dairy Sci. 86:1858-1863.

Lammers, B. P., D. R. Buckmaster, and A. J. Heinrichs. 1996. A simple method for the analysis of particle sizes of forage and total mixed rations. J. Dairy Sci. 79:922-928.

Leonardi, C., and L. E. Armentano. 2003. Effect of quantity, quality, and length of alfalfa hay on selective consumption by dairy cows. J. Dairy Sci. 86:557-564.

Maxin, G., D. R. Ouellet, and H. Lapierre. 2013. Effect of substitution of soybean meal by canola meal or distillers grains in dairy rations on amino acid and glucose availability . J. Dairy Sci. 96:78067817.

McCarthy, R. D. J., T. H. Klusmeyer, J. L. Vicini, J. H. Clark, and D. R. Nelson. 1989. Effects of source of protein and carbohydrate on ruminal fermentation and passage of nutrients to the small intestine of lactating cows. J. Dairy Sci. 72:2002-2016.

Mertens, D. R. 1997. Creating a system for meeting the fiber requirements of dairy cows. J. Dairy Sci. 80:1463-1481.

Nasrollahi, S. M., M. Khorvash, G. R. Ghorbani, A. Teimouri-Yansari, A. Zali, and Q. Zebeli. 2012. Grain source and marginal changes in forage particle size modulate digestive processes and nutrient intake of dairy cows. Animal 6:1237-1245.
Nocek, J. E., and S. Tamminga. 1991. Site of digestion of starch in the gastrointestinal tract of dairy cows and its effect on milk yield and composition. J. Dairy Sci. 74:3598-3629.

NRC. 2001. Nutrient Requirements of Dairy Cattle. 7th rev. ed. Natl. Acad. Sci., Washington, DC.

Oba, M., and M. S. Allen. 2003. Effects of corn grain conservation method on feeding behavior and productivity of lactating dairy cows at two dietary starch concentrations. J. Dairy Sci. 86:174183

Overton, T. R., M. R. Cameron, J. P. Elliott, J. H. Clark, and D. R. Nelson. 1995. Ruminal fermentation and passage of nutrients to the duodenum of lactating cows fed mixtures of corn and barley. J. Dairy Sci. 78:1981-1998.

Reynolds, C. K. 2006. Production and metabolic effects of site of starch digestion in dairy cattle. Anim. Feed Sci. Technol. 130:78-94.

Sadri, H., G. R. Ghorbani, H. R. Rahmani, A. H. Samie, M. Khorvash, and R. M. Bruckmaier. 2009. Chromium supplementation and substitution of barley grain with corn: Effects on performance and lactation in periparturient dairy cows. J. Dairy Sci. 92:5411-5418.

SAS Institute. 2003. SAS User's Guide. Version 9.1. SAS Institute Inc., Cary, NC.

Silveira, C., M. Oba, K. A. Beauchemin, and J. Helm. 2007. Effect of grains differing in expected ruminal fermentability on the productivity of lactating dairy cows. J. Dairy Sci. 90:2852-2859.

Sterk, A., B. E. O. Johansson, H. Z. H. Taweel, M. Murphy, A. M. vanVuuren, W. H. Hendriks, and J. Dijkstra. 2011. Effects of forage type, forage to concentrate ratio, and crushed linseed supplementation on milk fatty acid profile in lactating dairy cows. J. Dairy Sci. 94:6078-6091.

Tafaj, M., Q. Zebeli, C. Baes, H. Steingass, and W. Drochner. 2007. Review: A meta-analysis examining effects of particle size of total mixed rations on intake, rumen digestion and milk production in high-yielding dairy cows in early lactation. Anim. Feed Sci. Technol. 138:137-161.

Van Soest, P. J., J. B. Robertson, and B. A. Lewis. 1991. Methods for dietary fiber, neutral detergent fiber, and nonstarch polysaccharides in relation to animal nutrition. J. Dairy Sci. 74:3583-3597. 